restricted to modest levels, above which the authors should excuse themselves from writing guidelines. The professional societies that produce the guidelines should also consider introducing a ceiling on what authors can earn from relevant companies. Some organizations, such as the Institute for Clinical Systems Improvement, a Minnesota-based collaboration between US healthcare providers that produces advice on clinical practice, already have such criteria. There is no reason why others shouldn't follow suit.

But the time may also be ripe for a more radical overhaul of the system, particularly in the United States, where the financial stakes are highest and where the government currently plays almost no role. The organizations that produce the guidelines argue that it is impractical to exclude every individual with such a financial link from their preparation. But bodies in related spheres already do this. The Consensus Development Program at the National Institutes of Health, for example, which publishes advice on areas of clinical practice where there is debate about treatment options, operates a 'jury and witnesses' model, in which experts with financial links can only present evidence, not make judgements on it.

A similar mechanism could be set up at the US health department, for example, to steer the preparation of clinical guidelines. This would, of course, require modest public funding. Britain's National Institute for Health and Clinical Excellence, which receives government funding and devolves its decisions to external experts, provides a useful model.

But would such an organization be able to produce guidelines quickly enough? When a new drug becomes available, a team of physicians can review the evidence and make recom-
"A 'jury and witnesses' mechanism could be set up at the US health department to steer the preparation of guidelines." mendations in a few months. More sophisticated, consensus-based approaches typically take longer. But if it is adequately funded, such a body could produce guidelines expeditiously. If US physicians really want to separate marketing from medicine, they should support its creation.

\section{Grand ambition}

\section{Germany's coalition government is well placed to reform the country's scientific system.}

n most countries, the award of a Nobel prize is a cause of much self-congratulation. But not in Germany. When Theodor Hänsch won a share of this year's physics Nobel for his work on laserbased precision spectroscopy, many commentators saw the award as an exception to the rule of underperformance in German science.

Such introspection is all too characteristic of modern Germany. The truth is that German scientific prowess and inventiveness can still compete with the best in the world in many spheres. But the science system suffers from a number of structural weaknesses. The new government, almost certainly a 'grand coalition' of the two large political parties, the Social Democrats (SPD) and the Christian Democrats (CDU/CSU), should move quickly to address them. And the science ministry, which is likely to be led by Annette Schavan, a former minister for education in the state of Baden-Württemberg, should focus on areas where intervention is really needed.

It should start by revisiting Germany's restrictive rules and regulations in stem-cell research and plant biotechnology, which make it hard for researchers in Germany to be competitive. Former chancellor Gerhard Schröder had promised to open discussions on regulations that effectively prevent research using embryonic stem cells. Schavan said she wouldn't. This is one promise she should break.

Despite its long tradition in science, Germany still lacks research universities that can compete with the best in the United States and Britain. The federal education system, which distributes strong universities all over Germany, has served the country well. But to compete internationally, Germany needs to target a few institutions and support them to the hilt. The previous government launched a $€ 1.9$-billion (US\$2.3-billion) programme to strengthen the research profile of the best German universities. The new government will need to push this programme hard if it is to overcome state rivalries and allow the strongest research universities to grow stronger.

Across the university system as a whole, reforms are needed to ensure that appointments are made on merit. At present, political considerations and personal influence are often more important than a candidate's scientific strengths. If institute and department heads, and not ministry officials, were solely responsible for making appointments, this situation would change. Schavan says she wants the federal government to retreat from its joint responsibility for universities, and this could prove to be beneficial provided that the state (Länder) governments grant increased autonomy to the universities afterwards, as many of them have pledged to do.

Given a longer leash, universities could work harder to attract the best scientists from abroad. Germany has failed to make the most of the scientific talent in eastern Europe, despite its geographical proximity. While US universities rolled out the red carpet to immigrant scientists from that region, most German universities have not been flexible enough to create new positions, or to offer competitive salaries and conditions. The new government must help to put that right.

It should also take steps to
"The new government should work to create conditions that will keep women in research." make research careers more attractive for the dedining number of science students in Germany itself, and should create conditions that will keep women in research. It can start by nurturing merit-based appointments and providing incentives for employers to provide decent child care (see Nature 437, 296; 2005). Schavan, who calls herself a 'conservative feminist,' and Angela Merkel, the chancellordesignate and a former physicist, need to find ways to help more women achieve in science what they have done in politics.

Finally, money counts. Scientists will expect both coalition partners to stick to their pre-election commitments to gradually increase public science and education budgets. This also has a European dimension: it is unlikely, without Germany's active support, that the European Union's next Framework research programme will develop as it should. 